\title{
THE ROLE OF CHELATION AND OF HUMAN PLASMA IN THE UPTAKE OF SEROTONIN BY HUMAN PLATELETS *
}

\author{
By GRACE P. KERBY ANd S. M. TAYLOR
}

(From the Department of Medicine, Duke University Medical Center, Durham, N. C.)

(Submitted for publication July 6, 1960 ; accepted September 9, 1960)

Recent studies in this laboratory of platelets from patients with rheumatoid arthritis and nonrheumatoid inflammatory states (1) have emphasized the importance of the transport system or systems concerned with absorption and release of serotonin by platelets. There is no agreement or definite knowledge concerning such transport mechanisms at present. Born, Ingram and Stacey (2) reported a positive correlation between serotonin (5HT) absorption and ATP content in platelets, and Baker, Blaschko and Born (3) observed that $5 \mathrm{HT}$ and ATP were present in the same cytoplasmic fraction of platelets. Hughes, Shore and Brodie (4) felt that the rapid inhibition of uptake of serotonin produced by reserpine suggested blocking of an energetic transport mechanism for absorption, whereas the slow rate of release of serotonin from such platelets was consistent with passive diffusion. As regards an active absorption mechanism, Sano, Kakimoto and Taniguchi (5) noted a stimulatory effect of glucose on absorption of serotonin by rabbit platelets; they attributed this to ATP formed during glucose oxidation and suggested that ATP supplied the energy for absorption. However, inhibition of glucose metabolism did not result in slow release of serotonin as might have been expected with passive diffusion. An additional enzymatic mechanism for release was postulated therefore. Weissbach, Bogdanski and Udenfriend (6) and Weissbach, Redfield and Titus ( 7 ) called attention to the role of phosphates and potassium in the uptake of serotonin by saline suspensions of human platelets and to the inhibitory effect of cardiac glycosides on this system. They noted evidences for different mechanisms of uptake in different systems in vitro.

In the present study the problem of uptake of $5 \mathrm{HT}$ was explored by two types of experiments.

* This work was supported by grants from the National Institute of Arthritis and Metabolic Diseases, Bethesda, Md., and the American Heart Association.
I. Dye reduction by human platelets ${ }^{1}$; this method was used chiefly as a rapid screening test of in vitro systems in exploring for those consistently altered by addition of $5 \mathrm{HT}$. Such a system, defined by this method, was explored further by experiments of type II, the results of which could be subjected to more specific interpretation than could the redox studies. II. Measurable uptake of $5 \mathrm{HT}$ by human platelets in vitro.

Enzyme inhibitors which altered redox activity of platelets did not necessarily produce parallel alteration of $5 \mathrm{HT}$ effect on redox activity, indicating as might be expected that $5 \mathrm{HT}$ effect on redox activity was only one event added to the many metabolic reactions contributing to overall redox activity of the intact platelet. However and more specifically, platelet systems in which redox activity was altered by addition of $5 \mathrm{HT}$ showed parallel alteration in ability to take up added $5 \mathrm{HT}$ in vitro. Evidence obtained by the combined approach suggested that bound divalent cations of a nondialyzable plasma factor or factors were concerned with serotonin uptake in this system.

\section{METHODS}

Platelets were obtained from hospitalized patients with no evidence of primary hematologic, metabolic or malignant disease, and in most instances with no evidence of either rheumatoid or nonrheumatoid inflammatory states. Blood was drawn as previously noted (10), using disodium EDTA as anticoagulant. ${ }^{2}$ Platelets were

${ }^{1}$ Using 2,6-dichloroindophenol (DIPH). Intact platelets were used in all studies because in platelets, unlike most tissues, dehydrogenase activity appears to be dependent upon an intact cell structure (8). This finding of Koppel and Olwin was confirmed here and was not altered by separation of stroma or by inhibition of DPNase by nicotinamide, in experiments patterned after those of Alivisatos and Denstedt (9).

2 In a few experiments, native platelets were harvested from ambulatory subjects without use of anticoagulants. Dye reduction by these platelets was of the same general order of magnitude as that of platelets harvested from anticoagulated blood. 
harvested by differential centrifuging as in earlier studies (10). Initial suspension of the platelet buttons was in physiologic saline to a stock suspension having a standard photometric density of 0.500 [optical density (O.D.) $420 \mathrm{~m} \mu$ on a Coleman Junior spectrophotometer, saline blank]. Density readings were demonstrated to bear a linear relationship to serial dilutions of platelet suspensions.

I. Dye reduction by platelets. The method used was patterned closely after that of Chaudhuri and Martin (11) who worked with leukocytes. Identical readings were obtained with and without mineral oil seal, so mineral oil was omitted. To a $13 \times 100 \mathrm{~mm}$ glass tube, aligned in a rack behind its corresponding $12 \times 75 \mathrm{~mm}$ cuvet, was added $1.0 \mathrm{ml}$ of DIPH (stock $2.5 \mathrm{mg}$ DIPH per 100 $\mathrm{ml} 0.85$ per cent $\mathrm{NaCl}$ ). To each cuvet was added 1.0 $\mathrm{ml}$ of platelet suspension (now diluted as desired to O.D. ${ }_{420 \mathrm{~m} \mu}=0.125$ ) and $0.5 \mathrm{ml}$ of either $5 \mathrm{HT}^{3}$ or its solvent or a chelator in the same solvent. Optical densities were read serially on a Coleman Junior spectrophotometer at $600 \mathrm{~m} \mu$, mixing by pouring rapidly back and forth the contents of glass tube and its corresponding cuvet immediately before a zero reading was recorded and placing the cuvet immediately in a $37^{\circ} \mathrm{C}$ water bath. Readings were then recorded at 10, 20, 30 and $55 \mathrm{~min}$ utes after the zero reading. All reaction mixtures were run in duplicate (with close checks obtained uniformly and easily) and read against a blank of the same mixture with buffer substituted for DIPH.

Test substances-e.g., enzyme inhibitors-were incorporated in the platelet suspension or the DIPH solution as part of the diluent used for final dilution of these reactants. Platelets were kept iced and in siliconed glassware from time of first centrifugation until addition to cuvets. Basic platelet diluent was 0.85 per cent $\mathrm{NaCl}$.

${ }^{3}$ In creatinine sulfate form, as generously furnished by Abbott Laboratories and by the Upjohn Co.
Basic DIPH diluent was a buffered balanced salt solution ${ }^{4}$ at $\mathrm{pH} 7.4$, except as noted in a few experiments in which phosphate was eliminated from the system; here either veronal- $\mathrm{HCl}$ or Tris- $\mathrm{HCl}$ buffer (initial $6.7 \times$ $10^{-3} \mathrm{M}$ ) was used, each with added $\mathrm{NaCl}$ to 0.75 per cent and $\mathrm{KCl}$ to 0.075 per cent.

II. Measurable uptake of serotonin by platelets. Conditions under which addition of $5 \mathrm{HT}$ resulted in enhancement of DIPH dye reduction by platelets were adapted with appropriate controls to a system patterned after that used in earlier 5HT recovery experiments (1). Final flask volumes totaled $5 \mathrm{ml}$. All tests were run in duplicate or triplicate in a Warburg shaker water bath at $37^{\circ} \mathrm{C}$. $5 \mathrm{HT}$ and/or a chelator was added after one minute of equilibration at $37^{\circ} \mathrm{C}$, and each flask was placed in ice after exactly 20 minutes of further incubation. Separation and washing of platelets was carried out at $5^{\circ} \mathrm{C}$ as in earlier studies (10). Supernatant fluid obtained after centrifugation of the incubation medium was measured for per cent dye reduction in a Coleman Junior spectrophotometer at $600 \mathrm{~m} \mu$, using as blank the supernatant fluid of a platelet flask from which DIPH had been omitted; standard baseline was the O.D. ${ }^{000 \mathrm{~m} \mu}$ of identically-diluted DIPH without platelets. Platelets were then extracted and $5 \mathrm{HT}$ content measured fluorometrically as in previous studies (10). The presence of DIPH either within or bound to the washed platelets was evidenced by appearance of blue-dyed proteinaceous debris at the butanol-aqueous interface on first extraction of platelets with alkaline butanol. The intensity of blue dye in the debris appeared to be proportional to the $\mathrm{DIPH}$ remaining oxidized in the supernate which was

${ }^{4}$ Ten ml stock solution ( 7.5 per cent $\mathrm{NaCl}, 0.75$ per cent $\mathrm{KCl}, 0.1$ per cent $\mathrm{Na}_{2} \mathrm{HPO}_{4}, 0.12$ per cent $\mathrm{KH}_{2} \mathrm{PO}$, 0.05 per cent $\mathrm{K}_{2} \mathrm{HPO}_{4}$ ) and $7 \mathrm{ml} 1$ per cent $\mathrm{Na}_{2} \mathrm{HPO}_{4}$ per $100 \mathrm{ml}$, aqueous (total phosphate concentration, $6.7 \times$ $\left.10^{-3} \mathrm{M}\right)$.

TABLE I

Effect of various test substances on 2,6-dichloroindophenol (DIPH) dye reduction by human platelets in presence of plasma

\begin{tabular}{|c|c|c|c|c|c|}
\hline \multirow[b]{2}{*}{ Added to basic mixture* } & \multirow{2}{*}{$\begin{array}{l}\text { In final } \\
\text { conc. (M) }\end{array}$} & \multicolumn{4}{|c|}{$\%$ Dye reduced, test $-\%$ dye reduced, control } \\
\hline & & $10+$ & 20 & 30 & 55 \\
\hline Cyanide & $2 \times 10^{-4}$ & +5.7 & +9.4 & +11.8 & +16.3 \\
\hline Cyanide & $1 \times 10^{-2}$ & -11.1 & -20.9 & -27.7 & -23.9 \\
\hline Arsenatef & $1 \times 10^{-2}$ & -12.9 & -18.5 & -19.1 & -17.2 \\
\hline Fluoridef & $6 \times 10^{-3}$ & -7.9 & -8.4 & -6.3 & -3.6 \\
\hline Malonatef & $3.4 \times 10^{-3}$ & +8.7 & +13.6 & +12.8 & +9.5 \\
\hline 2,4-Dinitrophenol $\ddagger$ & $9 \times 10^{-4}$ & -7.3 & -5.6 & +1.9 & +13.0 \\
\hline Iodoacetate $\ddagger$ & $3.2 \times 10^{-3}$ & -35.3 & -52.4 & -59.4 & -61.0 \\
\hline Disodium EDTAf & $1.2 \times 10^{-2}$ & +17.1 & +21.9 & +19.5 & +13.8 \\
\hline Disodium calcium EDTAf & $1.2 \times 10^{-2}$ & +1.2 & $\begin{array}{r}+1.7 \\
+\end{array}$ & +1.2 & +0.7 \\
\hline $5 \mathrm{HT}$ creatinine $\mathrm{SO}_{4} \ddagger$ & $5 \times 10^{-4}$ & +13.2 & +16.3 & +13.8 & +8.4 \\
\hline
\end{tabular}

* Basic reaction mixture (final concentrations): $1.0 \mathrm{ml}$ platelet suspension (O.D. ${ }_{420 \mathrm{~m} \mu}=0.125$ ) in physiologic saline plus glucose $\left(1 \times 10^{3} \mathrm{M}\right) ; 4$ per cent added (in platelet suspension) platelet-free EDTA plasma (disodium EDTA final $\left.1.5 \times 10^{-4} \mathrm{M}\right) ; 0.5 \mathrm{ml}$ balanced buffered salt solution $\left(\mathrm{pH} / 7.4\right.$, phosphate $\left.4 \times 10^{-3} \mathrm{M}\right) ; 1.0 \mathrm{ml}$ DIPII dye (10 $\mu \mathrm{g}$ per $\mathrm{ml}$ balanced salt solution).

+ Time in minutes after zero point of mixing.

$\ddagger$ Sodium cyanide $\left(2 \times 10^{-4} \mathrm{M}\right)$ present in both test and control. 
removed prior to washing the platelets with saline and extracting.

\section{RESULTS}

$I-A$. Dye reduction by platelets. The effect of various added substances on dye reduction by platelets is summarized in Table I. Cyanide inhibition of dye reduction occurred at concentrations of $1 \times 10^{-2} \mathrm{M}$ but only in the presence of phosphate. Lower concentrations $\left(2 \times 10^{-4} \mathrm{M}\right)$ as used in the basic reactant mixture for evaluation of $5 \mathrm{HT}$ redox effect (see below) accelerated activity mildly in the presence of glucose and phosphate.

In the presence of plasma, using a standard final reactant mixture of platelets (O.D. ${ }_{420 \mathrm{~m} \mu}=$ $0.050)$, glucose $\left(1 \times 10^{-3} \mathrm{M}\right)$, cyanide $(2 \times$ $10^{-4} \mathrm{M}$ ) in buffered balanced salt solution (phosphate $\left.4 \times 10^{-3} \mathrm{M}\right)$, and 4 per cent added plateletfree EDTA plasma (disodium EDTA $1.5 \times$ $\left.10^{-4} \mathrm{M}\right), 5 \mathrm{HT}$ consistently and significantly enhanced dye reduction (Figure 1), unlike several related substances (Table II). This will be referred to hereinafter as the " $5 \mathrm{HT}$ redox effect." The 5HT effect was dependent upon the presence of platelets; the same system without platelets had minimal redox activity which was not altered by addition of 5HT. Alteration of the $5 \mathrm{HT}$ redox effect by added substances is summarized in Table III. Norepinephrine could not be substituted for 5HT with the same effect. Apparent partial inhibition of $5 \mathrm{HT}$ redox effect by large concentrations of reserpine appeared to result from an increase in dye reduction by platelets in presence of reserpine without a corresponding further increase on adding

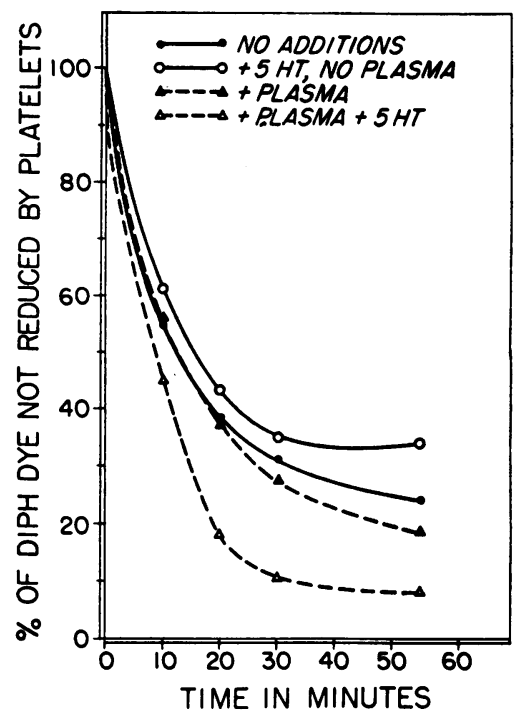

Fig. 1. Effect of Plasma and 5HT on DIPH dye REDUCTION BY HUMAN PLATELETS. Basic reactant mixture (final concentrations): $1.0 \mathrm{ml}$ platelet suspension in glucose $1 \times 10^{-3} \mathrm{M}$ in saline, O.D. ${ }_{420 \mathrm{~m} \mu}=0.050$, with (or as indicated without) 4 per cent added platelet-free EDTA plasma (disodium EDTA $1.5 \times 10^{-4} \mathrm{M}$ ) ; $0.5 \mathrm{ml}$ salt solution or $5 \mathrm{HT}$ (serotonin creatinine sulfate, $5 \times 10^{-4}$ $\mathrm{M}$ ) in balanced buffered salt solution ( $\mathrm{pH} 7.4$, phosphate $\left.4 \times 10^{-3} \mathrm{M}\right) ; 1.0 \mathrm{ml} \mathrm{DIPH}$ dye $10 \mu \mathrm{g}$ per $\mathrm{ml} \mathrm{NaCN}(2 \times$ $\left.10^{-4} \mathrm{M}\right)$ in balanced salt solution.

5HT. This applied also to apparent inhibition of $5 \mathrm{HT}$ redox effect by potential chelators including malonate and disodium EDTA $^{5}$ (Figure 2, A and $\mathrm{B})$, in contrast to the absolute inhibition produced

5 Disodium EDTA as (Ethylenedinitrilo) tetraacetic acid disodium salt, Eastman, or as generously supplied as Endrate Disodium and Endrate Disodium Calcium by Abbott Laboratories.

TABLE II

Comparison of effect of serotonin $(5 H T)$ and related substances on DIPH dye reduction by human platelets in presence and absence of plasma

\begin{tabular}{|c|c|c|c|c|c|}
\hline \multirow[b]{2}{*}{ Added to basic mixture* } & \multirow{2}{*}{$\begin{array}{l}\text { In final } \\
\text { conc. (M) }\end{array}$} & \multicolumn{4}{|c|}{$\%$ Dye reduced, test $-\%$ dye reduced, control } \\
\hline & & $10 \dagger$ & 20 & 30 & 55 \\
\hline $\begin{array}{l}\text { A. } 5 \mathrm{HT} \text { creatinine } \mathrm{SO}_{4} \\
\text { 5HIAA } \\
\text { Creatinine } \\
\text { Tryptamine } \mathrm{HCl}\end{array}$ & $\begin{array}{l}5 \times 10^{-4} \\
5 \times 10^{-4} \\
5 \times 10^{-4} \\
5 \times 10^{-4}\end{array}$ & $\begin{array}{l}-11.5 \\
+0.3 \\
+1.3 \\
-9.2\end{array}$ & $\begin{array}{l}-11.0 \\
-0.8 \\
+1.6 \\
-12.6\end{array}$ & $\begin{array}{l}-8.3 \\
-1.6 \\
+1.5 \\
-14.8\end{array}$ & $\begin{array}{l}-4.6 \\
-3.0 \\
+1.4 \\
-17.2\end{array}$ \\
\hline $\begin{array}{l}\text { B. } 5 \mathrm{HT} \text { creatinine } \mathrm{SO}_{4} \\
5 \mathrm{HIAA} \\
\text { Creatinine } \\
\text { Tryptamine } \mathrm{HCl}\end{array}$ & $\begin{array}{l}5 \times 10^{-4} \\
5 \times 10^{-4} \\
5 \times 10^{-4} \\
5 \times 10^{4}\end{array}$ & $\begin{array}{l}+16.0 \\
+\quad 1.8 \\
+0.6 \\
+4.7\end{array}$ & $\begin{array}{l}+14.3 \\
+\quad 1.4 \\
+0.3 \\
+\quad 4.2\end{array}$ & $\begin{array}{l}+8.8 \\
+0.3 \\
+0.2 \\
+\quad 1.7\end{array}$ & $\begin{array}{l}+4.9 \\
-0.3 \\
+0.1 \\
+1.0\end{array}$ \\
\hline
\end{tabular}

* Basic mixture same as in Table I except plasma onitted in A; $4 \%$ plasma added in B, as in Table I. Sodium cyanide $\left(2 \times 10^{-4} \mathrm{M}\right)$ present in both test and control.

$t$ 'Time in minutes after zero point of mixing. 
TABLE III

Effect of rarious test substances on $5 H T$ redox cffect* in human platelels

\begin{tabular}{|c|c|c|c|c|c|}
\hline \multirow[b]{2}{*}{ Added to basic mixture } & \multirow{2}{*}{$\begin{array}{l}\text { In final } \\
\text { conc. (M) }\end{array}$} & \multicolumn{4}{|c|}{$5 \mathrm{HT}$ redox effect, test $-5 \mathrm{HT}$ redox effect, control } \\
\hline & & $10 \ddagger$ & 20 & 30 & 55 \\
\hline Cyanide & $1 \times 10^{-2}$ & +0.2 & +2.2 & +4.3 & +7.1 \\
\hline Arsenate & $1 \times 10^{-2}$ & -0.3 & +0.1 & +2.6 & +2.1 \\
\hline Fluoride & $6 \times 10^{-3}$ & $\begin{array}{l}-9.4 \\
-9.4\end{array}$ & -17.9 & -19.7 & -21.7 \\
\hline Malonate & $3.4 \times 10^{-3}$ & -16.1 & -16.1 & -11.1 & -7.7 \\
\hline 2,4-Dinitrophenol & $9 \times 10^{-4}$ & -16.6 & -20.5 & -18.3 & -10.7 \\
\hline Iodoacetate & $3.2 \times 10^{-3}$ & -8.9 & -11.5 & -7.0 & -4.4 \\
\hline Disodium EDTA & $1.2 \times 10^{-2}$ & -17.1 & -21.9 & -19.5 & -13.8 \\
\hline Disodium calcium EDTA & $1.2 \times 10^{-2}$ & +0.3 & -1.5 & -1.1 & -0.6 \\
\hline Reserpine & $40 \mu \mathrm{g} / \mathrm{ml}$ & -9.0 & -9.8 & -8.1 & -4.5 \\
\hline Propylene glycol & $2.4 \mathrm{mg} / \mathrm{ml}$ & +1.9 & +1.8 & +0.2 & +0.2 \\
\hline
\end{tabular}

* Defined in text as the enhancement of DIPH dye reduction by platelets when serotonin (5HT) was added to the basic reactant mixture. Calculated here as per cent DIPH dye reduced in presence of $5 \mathrm{HT}$ minus per cent dye reduced in basic mixture alone.

$\dagger$ Basic reactant mixture as for Table I, including cyanide $2 \times 10^{-4} \mathrm{M}$.

$\ddagger$ Time in minutes after zero point of mixing.

by fluoride and by 2,4-dinitrophenol (Figure 2, C and $\mathrm{D}$ ). In further contrast, iodoacetate which markedly inhibited dye reduction by platelets (Table I) only partially inhibited $5 \mathrm{HT}$ redox effect (Table III); arsenate and cyanide $(1 \times$ $10^{-2} \mathrm{M}$ ) which inhibited dye reduction did not alter $5 \mathrm{HT}$ redox effect. Calcium EDTA $^{5}$ did not alter dye reduction by platelets or the $5 \mathrm{HT}$ redox effect, in contrast to disodium EDTA.

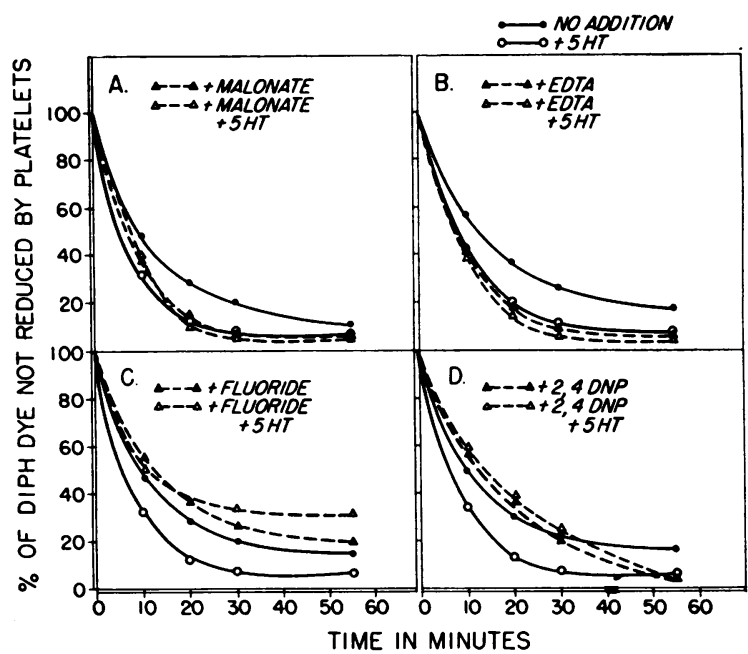

Fig. 2. Alteration OF 5HT Redox efFect by (A) MALONATE, (B) DISOdIUM EDTA, (C) Fluoride, AND (D) 2,4-Dinitrophenol. Results, I-A. Basic reactant mixture, same as Figure 1, including plasma. Additions as indicated above, incorporated in DIPH dye (A, C and D) or in platelet suspension (B) to final concentration: (A) malonic acid, neutralized with $\mathrm{NaOH}, 3.4 \times 10^{-3} \mathrm{M}$; (B) disodium EDTA, $8.6 \times 10^{-4} \mathrm{M}$; (C) sodium fluoride, $6 \times 10^{-3} \mathrm{M}$; (D) 2,4-dinitrophenol, $9 \times 10^{-4} \mathrm{M}$.
There was a linear relationship between concentration of either added $5 \mathrm{HT}$ or (within range 4 to $8 \times 10^{-4} \mathrm{M}$ ) disodium EDTA and enhancement of dye reduction by platelets (Figure 3 ). The effect of added $5 \mathrm{HT}\left(5 \times 10^{-4} \mathrm{M}\right)$ was roughly equivalent to that of disodium EDTA $(6.6 \times$ $\left.10^{-4} \mathrm{M}\right)$ in this regard. ${ }^{6}$ In studying the effect of

${ }^{6}$ It will be noted in Figure 3 that at lower concentrations of disodium EDTA, including the $1.5 \times 10^{-4} \mathrm{M}$ final concentration resulting from addition of EDTA plasma to some reactant mixtures, the linear relationship was no longer maintained. The effect of this concentration on dye reduction or on $5 \mathrm{HT}$ redox effect was relatively slight.

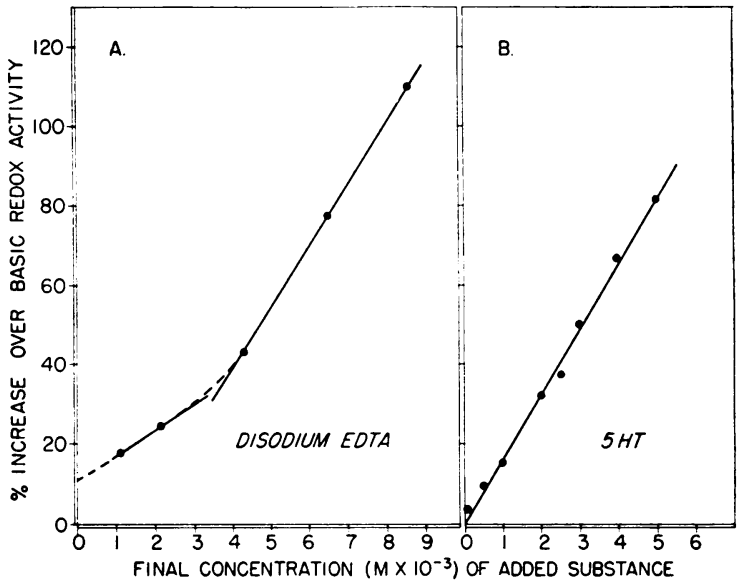

Fig. 3. Per cent increase in DIPH dye Reduction BY HUMAN PLATElets at 20 MINUTES With VARYiNG AMOUNTS OF ADDED (A) DISOdIUM EDTA OR (B) $5 \mathrm{HT}$. Basic reactant mixture, same as in Figure 1, including plasma. Disodium EDTA and 5HT (serotonin creatinine sulfate) in final concentrations as indicated. 
added $\mathrm{Ca}^{++}$on the $5 \mathrm{HT}$ redox effect, increasing turbidity and precipitate during incubation of some systems suggested possible formation of calcium soaps. A system patterned in principle after that of Gomori (12) was designed to investigate this possibility by omitting DIPH from the system and recording turbidities at $420 \mathrm{~m} \mu$. While formation of calcium soaps was not ruled out in view of the secondary and considerable rise in turbidity noted in Figure 4A, it was apparent from experiments omitting platelets that formation of calcium phosphate was a more likely explanation of events. Calcium phosphate was solubilized by $5 \mathrm{HT}$ (Figure $4 \mathrm{~B})$.

I-B. The plasma factor necessary for $5 H T$ redox effect. Enhancement of dye reduction by either $5 \mathrm{HT}$ or disodium EDTA occurred only in the presence of added plasma. The plasma effect was maximal at plasma concentrations of 2 to 4 per cent (Figure 5). Plasma dialyzed exhaustively against a balanced buffer, $\mathrm{pH} 7.4$ (phosphate or veronal or Tris), was fully active in the system. Autologous plasma was as active as homologous plasma. Refrigerated aging of plasma for at least 1 week did not decrease its activity in the system. Rapid freezing and thawing six times had no effect on activity of plasma in the system,

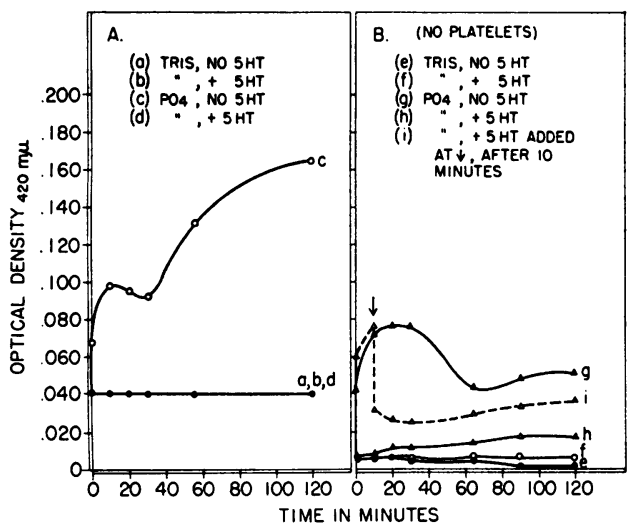

Fig. 4. EFFECT OF 5HT ON TURBIDITy OF MIXTURES OF CALCIUM ACETATE AND PHOSPHATE BUfFER, (A), IN PRESence of platelets, and (B) Without platelets. No plasma present. Final concentrations : $1.0 \mathrm{ml}$ platelets or glucose-saline $+\mathrm{Ca}^{++} ; 1.0 \mathrm{ml}$ buffer $+\mathrm{NaCN}\left(2 \times 10^{-4} \mathrm{M}\right)$ (Tris or phosphate buffer $4 \times 10^{-3} \mathrm{M}+\mathrm{NaCl} 0.03 \%+$ $\mathrm{KCl} 0.003 \%$ ); $0.5 \mathrm{ml}$ buffer or $5 \mathrm{HT}$, serotonin creatinine sulfate) $5 \times 10^{-4} \mathrm{M}$ in buffer indicated above. Platelets suspended in glucose initial $2.5 \times 10^{-3} \mathrm{M}$ in saline + calcium acetate initial $12.5 \times 10^{-3} \mathrm{M}$ and held in ice bath for several hours before use.

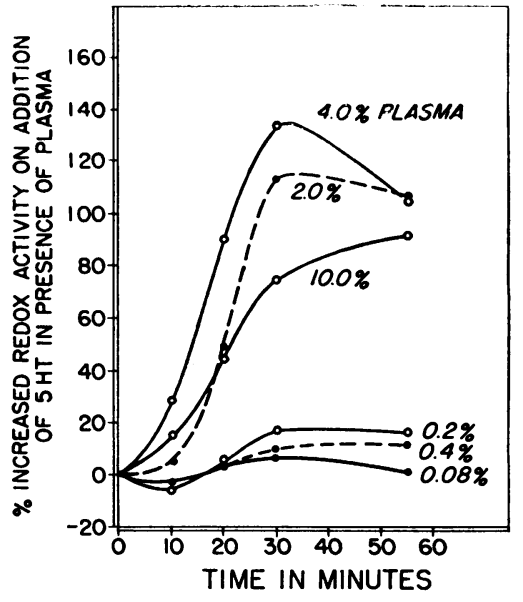

Fig. 5. Comparison of DEgreE of ENHANCEMENT OF DYE REDUCTION BY HUMAN PLATELETS BY 5HT IN PRESENCE OF VARYING CONCENTRATIONS OF PLATELET-FREE EDTA PLASMA (EDTA $3.8 \times 10^{-3} \mathrm{M}$ IN ORIGINAL PLASMA). Basic reactant mixture as in Figure 1. 5HT (as creatinine sulfate salt) added in final $5 \times 10^{-4} \mathrm{M}$ concentration.

nor did heating to $37^{\circ}$ or to $56^{\circ} \mathrm{C}$ for 30 minutes diminish its activity. Activity in the system was decreased after 15 minutes at $80^{\circ} \mathrm{C}$ and destroyed by 5 minutes at $100^{\circ} \mathrm{C}$. Butanol extraction of plasma at $25^{\circ} \mathrm{C}$ was without effect on activity of the supernatant plasma. Euglobulin obtained by isoelectric precipitation at $\mathrm{pH} 5.8$ could not be substituted for plasma, nor could the remaining supernatant plasma (after restoration to $\mathrm{pH} 7.4$ ), raising the question of irreversible damage to the factor by $\mathrm{pH}$ change. Cohn fractions ${ }^{7}$ II, IV-1, IV-4, and V could not be substituted for plasma. Trial of other Cohn fractions of plasma was unsatisfactory due to their denatured state as indicated by partial insolubility in saline.

Phosphate in final concentration and at $\mathrm{pH}$ indicated by Weissbach and colleagues (6) for promotion of $5 \mathrm{HT}$ uptake by platelets could not be substituted for plasma in the redox system. Elimination of phosphates by dialysis of plasma against veronal or Tris buffer did not abolish the $5 \mathrm{HT}$ redox effect.

II. Measurable uptake of scrotonin by platelets. Results are summarized in Tables IV and V, including single readings on per cent reduction of

7 Obtained from E. R. Squibb \& Sons, through the courtesy of Dr. J. N. Ashworth of the American National Red Cross. 
TABLE IV

Influcnce of plasma, chelators and magnesium on the uptakc of added serotonin by human platclets in vitro

\begin{tabular}{|c|c|c|}
\hline Flask mixture* & $5 \mathrm{HT} \dagger$ & DIPH redox dyet \\
\hline $\begin{array}{l}\text { to } 5 \mathrm{ml} \text { vol } \\
\text { a. } \mathrm{PT}(0.104)+\mathrm{G}+\mathrm{B}+\mathrm{CN}+5 \mathrm{HT}\left(5 \times 10^{-4} \mathrm{M}\right)+\mathrm{D} \\
\text { Same }+4 \% \mathrm{PL} \\
\mathrm{PT}(0.104)+\mathrm{G}+\mathrm{B}+\mathrm{CN}+5 \mathrm{HT}\left(5 \times 10^{-5} \mathrm{M}\right)+\mathrm{D} \\
\text { Same }+4 \% \mathrm{PL}\end{array}$ & $\begin{array}{l}\text { Total } \mu g \\
2.8(\mathrm{~d} 8.1 \%) \\
4.1 \text { (d } 5.6 \%) \\
1.5(\mathrm{~d} 11.5 \%) \\
2.5(\text { d } 5.8 \%)\end{array}$ & $\begin{array}{l}\text { \% reduction } \\
\quad 58.1 \\
91.3 \\
61.7 \\
92.7\end{array}$ \\
\hline $\begin{array}{l}\text { b. } \mathrm{PT}(0.102)+\mathrm{G}+\mathrm{B}+\mathrm{CN}+5 \mathrm{HT}+\mathrm{D} \\
\text { Same }+4 \% \mathrm{PL} \\
\text { Same }+4 \% \mathrm{PL}+\mathrm{E}\end{array}$ & $\begin{array}{l}1.4(\mathrm{t} 7.9 \%) \\
1.9(\mathrm{t} 4.4 \%) \\
2.3(\mathrm{t} 4.7 \%)\end{array}$ & $\begin{array}{l}30.0 \\
61.2 \\
74.7\end{array}$ \\
\hline $\begin{array}{l}\text { c. } \mathrm{PT}(0.104)+\mathrm{G}+\mathrm{B}+\mathrm{CN}+5 \mathrm{HT}+\mathrm{D}+4 \% \mathrm{PL}+\mathrm{E} \\
\text { Same }+\mathrm{Mg} \text {. } \\
\text { Same + } \mathrm{Mg} \text { except no } \mathrm{E}\end{array}$ & $\begin{array}{l}2.0(\mathrm{t} 4.7 \%) \\
1.4(\mathrm{t} 4.3 \%) \\
2.0(\mathrm{t} 9.3 \%)\end{array}$ & $\begin{array}{l}77.8 \\
57.6 \\
64.8\end{array}$ \\
\hline $\begin{array}{l}\text { d. } \mathrm{PT}(0.104)+\mathrm{G}+\mathrm{B}+\mathrm{CN}+5 \mathrm{H}^{\prime} \mathrm{T}+\mathrm{D}+4 \% \mathrm{PL} \\
\text { Same }+\mathrm{Mg} \\
\text { Same (no Mg) }+\mathrm{CE}\end{array}$ & $\begin{array}{l}1.6(\mathrm{t} 0 \%) \\
1.6(\mathrm{t} 4.5 \%) \\
1.6(\mathrm{t} 5.8 \%)\end{array}$ & $\begin{array}{l}54.4 \\
54.0 \\
51.8\end{array}$ \\
\hline
\end{tabular}

* Final concentrations, except plasma EDTA: PT = platelet suspension (O.D. $420 \mathrm{~m} \mu$ ) in physiologic saline. G $=$ glucose, $1 \times 10^{-3} \mathrm{M}$. B = balanced buffered salt solution $\left(\mathrm{PO}_{4}=4 \times 10^{-3} \mathrm{M} ; \mathrm{pH} 7.4\right)$. CN = sodium cyanide, $2 \times 10^{-4} \mathrm{M}$. $5 \mathrm{HT}=$ serotonin creatinine sulfate, $5 \times 10^{-5} \mathrm{M}$ unless otherwise stated. $\mathrm{D}=2$,6-dichloroindophenol $(\mathrm{DIPH}), 20 \mu \mathrm{g}$ per $\mathrm{ml}$. $\mathrm{PL}=$ platelet-free plasma with disodium EDTA $3.8 \times 10^{-3} \mathrm{M}$ as harvested. $\mathrm{E}=$ disodium EDTA, $1.2 \times 10^{-2} \mathrm{M}$. $\mathrm{CE}=$ disodium calcium EDTA, $1.2 \times 10^{-2} \mathrm{M} . \mathrm{Mg}=\mathrm{MgSO}_{4} 7 \mathrm{H}_{2} \mathrm{O}, 8.1 \times 10^{-3} \mathrm{M}$.

$t$ Since each experiment was a comparative unit, endogenous and added $5 \mathrm{HT}$ are expressed as a combined total, as $5 \mathrm{HT}$ creatinine sulfate, with per cent deviation of duplicate $(\mathrm{d})$ or triplicate $(\mathrm{t})$ flasks in parentheses.

$\ddagger 100$ minus $\frac{\text { O.D. } 600 \mathrm{~m} \mu \text { of supernatant fluid }}{\text { standard original O.D. } 600 \mathrm{~m} \mu \times 100} \times 100=\%$ reduction DIPH dye.

DIPH dye at 20 minutes in the supernatant fluid of reaction flasks where this was feasible (Table IV). The 5HT uptake was observed to correlate with degree of reduction of dye. Enhanced uptake of 5HT occurred under conditions comparable with those in which 5HT redox effect was observed (Table IV, a), and this was further enhanced by addition of disodium EDTA (b) but not by addition of disodium calcium EDTA (d). Addition of $\mathrm{Mg}^{++}$was without effect in the system (c, d) unless combined with chelators. Although $\mathrm{Mg}^{++}$chelates have a lower stability constant than have $\mathrm{Ca}^{++}$.chelates, the small amount of $\mathrm{Ca}^{++}$displaced in arriving at an equilibrium after addition of $\mathrm{Mg}^{++}$to disodium calcium EDTA sufficed to produce the gel which was seen regularly on in-

TABLE V

Influence of phosphates on uptake of serotonin by human platelets, with and without added plasma, DIPH redox dye and chelators, in vitro

\begin{tabular}{|c|c|}
\hline Flask mixture (to volume $5 \mathrm{ml}$ )* & $\underset{5 \mathrm{HTt}}{\text { Total } \mu \mathrm{g}}$ \\
\hline $\begin{array}{l}\text { a. } \mathrm{PT}(0.188)+\mathrm{B}+5 \mathrm{H}^{\prime} \mathrm{T}\left(5 \times 10^{-6} \mathrm{M}\right) \\
\text { Same }+(\mathrm{W}) \mathrm{B} ; \text { no } \mathrm{PL}\end{array}$ & $\begin{array}{l}4.5(\mathrm{~d} 2.3 \%) \\
7.7(\mathrm{~d} 8.0 \%)\end{array}$ \\
\hline $\begin{array}{l}\text { b. } \mathrm{PT}(0.188)+\mathrm{G}+\mathrm{B}+5 \mathrm{HT}\left(5 \times 10^{-6} \mathrm{M}\right) \\
\text { Same }+(\mathrm{W}) \mathrm{B} ; \text { no } \mathrm{PL}\end{array}$ & $\begin{array}{l}2.5(\mathrm{~d} 1.8 \%) \\
3.5(\mathrm{~d} 1.3 \%)\end{array}$ \\
\hline $\begin{array}{l}\text { c. } \mathrm{PT}(0.104)+\mathrm{G}+\mathrm{B}+\mathrm{CN}+5 \mathrm{HT}+\mathrm{D}+4 \% \mathrm{PL} \\
\text { Same }+(\mathrm{W}) \mathrm{B} \\
\text { Same }+(\mathrm{W}) \mathrm{B} \text { except no PL }\end{array}$ & $\begin{array}{l}2.2(\mathrm{t} 4.5 \%) \\
2.0(\mathrm{t} 8.5 \%) \\
1.1(\mathrm{t} 11.2 \%)\end{array}$ \\
\hline $\begin{array}{l}\text { d. } \mathrm{PT}(0.105)+\mathrm{G}+\mathrm{B}+\mathrm{CN}+5 \mathrm{HT}+\mathrm{D}+4 \% \mathrm{PL} \\
\text { Same }+(\mathrm{W}) \mathrm{B} \\
\text { Same }+(\mathrm{W}) \mathrm{B}+\mathrm{E}\end{array}$ & $\begin{array}{l}2.0(\mathrm{t} 2.3 \%) \\
1.8(\mathrm{t} 5.0 \%) \\
1.8(\mathrm{t} 2.6 \%)\end{array}$ \\
\hline
\end{tabular}

* Final concentrations, except plasma EDTA: PT = platelet suspension (O.D.420 $\mathrm{m} \mu$ ) in physiologic saline. B= balanced buffered salt solution $\left(\mathrm{pH} 7.4\right.$, phosphate $\left.4 \times 10^{-3} \mathrm{M}\right)$. (W) $\mathrm{B}=$ phosphate buffer $5 \times 10^{-2} \mathrm{M}$, as used by Weissbach and co-workers (6). $5 \mathrm{HT}=$ serotonin creatinine sulfate $\left(5 \times 10^{-5} \mathrm{M}\right.$ unless otherwise stated $) . \quad \mathrm{PL}=$ platelet-free plasma with disodium EDTA $3.8 \times 10^{-3} \mathrm{M}$ as harvested. $\mathrm{G}=$ glucose $\left(1 \times 10^{-3} \mathrm{M}\right) . \mathrm{CN}=$ sodium cyanide $\left(2 \times 10^{-4} \mathrm{M}\right) . \quad \mathrm{D}=2,6$-dichloroindophenol $(\mathrm{DIPH}), 20 \mu \mathrm{g}$ per $\mathrm{ml} . \quad \mathrm{E}=$ disodium EDTA, $1.2 \times 10^{-2} \mathrm{M}$.

t Same as for Table IV. 
troduction of excess free $\mathrm{Ca}^{++}$into the in vitro system used in these experiments. The gel prevented measurement of uptake of 5HT. However, when $\mathrm{Mg}^{++}$was added with disodium EDTA, uptake of $5 \mathrm{HT}$ was sharply curtailed and redox activity was reduced (Table IV, c).

Addition of phosphate buffer in concentration $5 \times 10^{-2} \mathrm{M}$ and at $\mathrm{pH} 7.0$, as used by Weissbach and colleagues (6), to human platelets in balanced salt solution (phosphate $6.7 \times 10^{-3} \mathrm{M}$ ) resulted in markedly enhanced uptake of $5 \mathrm{HT}$ (Table $\mathrm{V}, \mathrm{a}$ ) as noted by these investigators. The degree of enhancement was reduced by addition of glucose to the system (Table $\mathrm{V}, \mathrm{b}$ ). On completion of the system by addition of plasma, cyanide and DIPH, no enhancement of uptake occurred on addition of the higher concentration of phosphate, and reduction rather than enhancement of $5 \mathrm{HT}$ uptake by platelets occurred when the higher concentration of phosphate was substituted for added plasna (c). Disodium EDTA did not enhance $5 \mathrm{HT}$ uptake in presence of the higher concentration of phosphate (Table $\mathrm{V}, \mathrm{d}$ ), in contrast to the enhancement noted in presence of low concentrations of phosphate (Table IV, b).

\section{DISCUSSION}

The problem of serotonin uptake by human platelets was approached 1) by a screening method which defined certain systems in which dye (DIPH) reduction by intact human platelets in vitro was consistently altered by adding $5 \mathrm{HT}$ in the presence of plasma ("5HT redox effect"), and 2) by measuring uptake of $5 \mathrm{HT}$ by intact human platelets in vitro in the systems so defined.

The over-all data on effect of enzyme inhibitors on dye reduction by human platelets (Table I) reemphasized the active metabolic state of these cytoplasmic particles, as has been recognized previously and reviewed by Zucker and Borrelli (13). They were useful in the present studies chiefly as a basis of comparison (Tables I to III) for investigating the $5 \mathrm{HT}$ redox effect, as just defined. Agents which inhibited over-all ability of platelets to reduce DIPH dye did not necessarily inhibit to a comparable degree the enhancing effect of $5 \mathrm{HT}$ on dye reduction in the presence of plasma (see Results, I-A). This emphasized well that over-all redox activity is a cumulative result of many metabolic activities and that alteration of redox activity by $5 \mathrm{HT}$ in the presence of plasma was but one added factor in the over-all picture. The observation might or might not have been meaningful in terms of reflecting change in the only known and previously measured physiologic activity of platelets in regard to $5 \mathrm{HT}$-i.e., uptake of 5HT. However, the results of uptake studies showed a parallelism between $5 \mathrm{HT}$ redox effect and 5HT uptake in that both were accelerated by added disodium EDTA, both were unaffected by disodium calcium EDTA, and both were sharply retarded by magnesium in the presence of disodium EDTA (but not by magnesium alone). In neither type of experiment were these effects observed in absence of plasma, and substitution of nonphysiologically high concentrations of phosphate $\left(5 \times 10^{-2} \mathrm{M}\right)$ for plasma resulted in decreased rather than enhanced uptake of $5 \mathrm{HT}$. This emphasized the comments of Weissbach and co-workers (7) regarding the existence of different mechanisms for uptake in different systems in vitro. The high concentrations of phosphate found by these investigators (and confirmed here and elsewhere) to enhance uptake of 5HT in saline suspension of human platelets in vitro showed diminishing ability to enhance uptake when glucose was added to the system and retardation of uptake when cyanide and a hydrogen acceptor were further added. However, when plasma was present in the system, addition of the high concentration of phosphate was without any effect on uptake. Since the plasma factor or factors were active after prolonged dialysis, either large molecules per se or small substances bound to large molecules seemed implicated in uptake under the particular in vitro conditions employed. Two findings were then pertinent in this regard: 1) $5 \mathrm{HT}$ could solubilize calcium phosphate; 2) in presence of plasma, both the $5 \mathrm{HT}$ redox effect and $5 \mathrm{HT}$ uptake by human platelets in presence of plasma were sharply curtailed when another divalent cation $\left(\mathrm{Mg}^{++}\right)$was first added and then chelated with disodium EDTA. This suggested the possibility that in this in vitro system $5 \mathrm{HT}$ complexed with a divalent ion bound to a large molecular plasma component as part of the process of uptake by platelets. This could be prevented by prior complexing of $5 \mathrm{HT}$ with free divalent ions and then binding with disodium EDTA. Whether these observations have any bearing on 
the earlier hypotheses of Woolley $(14,15)$ regarding a tissue "portering substance," which could combine with serotonin and with calcium ions and diffuse across cellular membranes, must await further studies. The nature of the plasma factor or factors influencing serotonin uptake in the present studies is being investigated currently, as well as the presence of the factor or factors in various human disease states related to connective tissue.

\section{SUMMARY}

1. The problem of uptake of serotonin by human platelets was investigated by 1 ) a screening method which measured dye (2,6-dichloroindophenol) reduction by intact platelets, and 2) measurable uptake of serotonin by intact platelets, all in the presence of human plasma. The effect of various agents on these in vitro systems was observed.

2. Enhancement of dye reduction by platelets in the presence of serotonin and a plasma factor or factors (" $5 \mathrm{HT}$ redox effect") correlated with increased uptake of serotonin by intact platelets.

3. Serotonin was shown to solubilize calcium phosphate in vitro. Prior mixing of serotonin with $\mathrm{Mg}^{++}$followed by chelation with disodium EDTA markedly diminished both $5 \mathrm{HT}$ redox effect and uptake of $5 \mathrm{HT}$ by intact human platelets in the presence of plasma. Disodium calcium EDTA was without effect, as was $\mathrm{Mg}^{++}$alone.

4. The possibility is entertained that in the presence of a factor present in human plasma, serotonin is taken up by human platelets as a complex with a divalent cation bound to a heat-stable, nondialyzable plasma factor.

\section{REFERENCES}

1. Kerby, G. P., and Taylor, S. M. In vitro absorption of serotonin by thrombocytes of rheumatoid arthritic and non-arthritic individuals. Proc. Soc. exp. Biol. (N. Y.) 1959, 102, 45.

2. Born, G. V. R., Ingram, G. I. C., and Stacey, R. S. The relationship between 5-hydroxytryptamine and adenosine triphosphate in blood platelets. Brit. J. Pharmacol. 1958, 13, 62.

3. Baker, R. V., Blaschko, H., and Born, G. V. R. The isolation from blood platelets of particles containing 5-hydroxytryptamine and adenosine triphosphate (abstract). J. Physiol. (Lond.) 1959, 149, 55P.

4. Hughes, F. B., Shore, P. A., and Brodie, B. B. Serotonin storage mechanism and its interaction with reserpine. Experientia (Basel) 1958, 14, 178.

5. Sano, I., Kakimoto, Y., and Taniguchi, K. Binding and transport of serotonin in rabbit blood platelets and action of reserpine. Amer. J. Physiol. 1958, 195, 495.

6. Weissbach, H., Bogdanski, D. F., and Udenfriend, S. Binding of serotonin and other amines by blood platelets. Arch. Biochem. 1958, 73, 492.

7. Weissbach, H., Redfield, B. G., and Titus, E. Effect of cardiac glycosides and inorganic ions on binding of serotonin by platelets. Nature (Lond.) 1960, 185, 99.

8. Koppel, J. L., and Olwin, J. H. Dehydrogenase activity of human platelets. Proc. Soc. exp. Biol. (N. Y.) $1954,86,641$.

9. Alivisatos, S. G. A., and Denstedt, O. F. Nicotinamide inhibition of tri- and diphosphopyridine nucleotide-linked dehydrogenases. J. biol. Chem. 1952, 199, 493.

10. Kerby, G. P., and Taylor, S. M. The acid mucopolysaccharide and 5-hydroxytryptamine content of human thrombocytes in rheumatoid arthritic and nonarthritic individuals. J. clin. Invest. 1959, 38, 1059.

11. Chaudhuri, S. N., and Martin, S. P. The migration and oxidation-reduction activity of leukocytes from patients with acute disseminated lupus erythematosus. J. Lab. clin. Med. 1953, 41, 108.

12. Gomori, G. Histochemical demonstration of sites of choline esterase activity. Proc. Soc. exp. Biol. (N. Y.) 1948, 68, 354.

13. Zucker, M. B., and Borrelli, J. A survey of some platelet enzymes and functions: The platelets as the source of normal serum acid glycerophosphatases. Ann. N. Y. Acad. Sci. 1958, 75, 203.

14. Woolley, D. W. A probable mechanism of action of serotonin. Proc. Nat. Acad. Sci. 1958, 44, 197.

15. Woolley, D. W. Serotonin receptors. I. Extraction and assay of a substance which renders serotonin fat-soluble. Proc. Nat. Acad. Sci. 1958, 44, 1202. 